\title{
Communication
}

\section{Commercial Spirits for Surfactant-Free Syntheses of Electro-Active Platinum Nanoparticles}

\author{
Jonathan Quinson ${ }^{1, * \mathbb{D}}$, Søren Bredmose Simonsen ${ }^{2} \mathbb{D}$, Luise Theil Kuhn ${ }^{2}$ and Matthias Arenz ${ }^{3}(\mathbb{D}$ \\ 1 Department of Chemistry, University of Copenhagen, Universitetsparken 5, 2100 Copenhagen, Denmark \\ 2 Department of Energy Conversion and Storage, Technical University of Denmark, Fysikvej Bldg. 310, \\ 2800 Kgs. Lyngby, Denmark; sobrs@dtu.dk (S.B.S.); luku@dtu.dk (L.T.K.) \\ 3 Department of Chemistry and Biochemistry, University of Bern, Freiestrasse 3, CH-3012 Bern, Switzerland; \\ matthias.arenz@dcb.unibe.ch \\ * Correspondence: jonathan.quinson@chem.ku.dk
}

Citation: Quinson, J.; Simonsen, S.B.; Theil Kuhn, L.; Arenz, M.

\section{Commercial Spirits for}

Surfactant-Free Syntheses of Electro-Active Platinum

Nanoparticles. Sustain. Chem. 2021, 2,

1-7. https://doi.org/10.3390/

suschem2010001

Received: 23 November 2020

Accepted: 24 December 2020

Published: 4 January 2021

Publisher's Note: MDPI stays neutral with regard to jurisdictional clai$\mathrm{ms}$ in published maps and institutional affiliations.

Copyright: () 2021 by the authors. Licensee MDPI, Basel, Switzerland. This article is an open access article distributed under the terms and conditions of the Creative Commons Attribution (CC BY) license (https:// creativecommons.org/licenses/by/ $4.0 /)$.

\begin{abstract}
The Co4Cat ${ }^{\mathrm{TM}}$ process is a simple, surfactant-free method to produce colloidal dispersions of precious metal nanoparticles in alkaline mono-alcohols. The synthesis is performed in lowboiling-point solvents and is relevant for industrial production. The robustness of the process is demonstrated by using three different commercial spirits as solvents to obtain Pt nanoparticles. The results demonstrate that careful control of the solvent purity is not needed to achieve the synthesis of stable $2 \mathrm{~nm}$ platinum nanoparticle colloids readily active electrocatalysts for energy conversion reactions like the methanol oxidation.
\end{abstract}

Keywords: colloids; Co4Cat technology; nanoparticles; platinum; solvent

\section{Introduction}

Precious metal catalysts are used in strategic fields of applications like energy conversion [1], chemical production [2], pollution treatment [3], or medical applications [4]. To make the most of the limited resources down to the atomic scale, precious metal nanoparticles (NPs) with high surface-to-volume ratios are desired but several challenges remain for their large-scale sustainable production [5-8]. A first challenge is to achieve size control on the nanoscale. A second challenge is to identify suitable production routes. Among various options, wet chemical syntheses lead to NP colloidal dispersions with several industrial advantages. Colloidal syntheses are relatively simple and fast while they typically show satisfying scalability and reliable control over the NP properties [9].

In colloidal approaches, NPs are often obtained by reducing a metal precursor in a solvent in presence of surfactants to control size, stability, and/or morphology $[2,8,10]$. However, surfactants can negatively affect the properties of the NPs, especially for catalytic applications by 'blocking' the catalytically active surface [11,12]. Surfactant removal is, therefore, usually required and performed by procedures that typically require harsh thermal/chemical treatments $[13,14]$. Surfactants are also undesired for more sustainable synthesis of nanomaterials since they are often derived from petroleum resources and ultimately can be considered as waste products.

Surfactant-free syntheses are promising alternatives. We reported the synthesis of $\mathrm{Pt}$ NPs in mixture of mono-alcohols and water using alkaline low-boiling-point $\left(<80^{\circ} \mathrm{C}\right)$ solvents, thus addressing the main challenges in implementing colloidal syntheses at larger scale [15]. This Co4Cat ${ }^{\mathrm{TM}}$ technology leads to NPs with enhanced catalytic activity compared to state of the art in heterogeneous catalysis and electrochemical reactions $[15,16]$. The synthesis is robust regarding the mode of production (thermal [17], ambient conditions [18], using UV light [19], etc.), upscaling the volume of reaction, the concentration of metal precursor, etc., to name only a few of the experimental parameters investigated to date $[20,21]$. 
Our previous studies focused on the size control of surfactant-free NPs in well-defined conditions, e.g., high-purity water (Milli-Q, Millipore), research-grade chemicals, etc. It is, however, known that the chemical grade of reactants and solvents can impact NP synthesis $[22,23]$. Lower-grade solvents are also cheaper, which is directly relevant for large-scale production. We here investigated a step further the robustness of the synthesis by selecting three commercial and consumer-grade spirits to produce platinum (Pt) NPs: a rum, a gin, and a vodka.

\section{Materials and Methods}

\subsection{Synthesis}

All chemicals were used are received: $\mathrm{H}_{2} \mathrm{PtCl}_{6} \cdot 6 \mathrm{H}_{2} \mathrm{O}$ (99.9 \% Alfa Aesar); $\mathrm{NaOH}(98 \%$, Alfa Aesar); ethanol (99.9\%, Kemetyl); water (Milli-Q, Millipore, resistivity $>18.2 \mathrm{M} \Omega \cdot \mathrm{cm}$, total organic carbon (TOC) < 5 ppb); Captain Morgan White Rum (37.5 v.\% ethanol); Cuba Pure Vodka - Premium vodka (37.5 v.\% ethanol); GMG London dry Gin (37.5 v.\% ethanol); methanol ( $\geq 99.8 \%$, VWR); ethanol ( $\geq 99.8 \%$, VWR) and KOH (EMSURE ${ }^{\circledR}$, Merck Millipore). A control solution was used by mixing Milli-Q water and ethanol in a volume ratio of $37.5 \mathrm{v} . \%$ ethanol.

The synthesis of the NPs was performed by preparing a reaction mixture of $10 \mathrm{~mL}$ containing $0.5 \mathrm{mM} \mathrm{H}_{2} \mathrm{PtCl}_{6}$ in one of the four alkaline solvents studied: a control solvent (Control, 37.5 v.\% ethanol in water), Gin, Vodka, or Rum so that the $\mathrm{NaOH} / \mathrm{Pt}$ molar ratio was 20. The reaction mixtures were heated up for $30 \mathrm{~min}$ using a microwave oven (CEM Discover SP, $100 \mathrm{~W}$ ) using a reflux setup configuration. While the solution was irradiated, a flow of $\mathrm{N}_{2}$ was passed on the outside of the vessel to cool it down; otherwise the temperature rose too quickly. No stirring was performed.

The synthesis of the NPs was alternatively performed by preparing a reaction mixture of $8 \mathrm{~mL}$ containing $2.5 \mathrm{mM} \mathrm{H}_{2} \mathrm{PtCl}_{6}$ in one of the four alkaline solvents studied: Control, Gin, Vodka or Rum so that the $\mathrm{NaOH} / \mathrm{Pt}$ molar ratio was 20 . The reaction mixture were heated up for $60 \mathrm{~min}$, as described in the previous paragraph.

\subsection{Transmission Electron Microscopy (TEM)}

The NPs were characterized by TEM after dropping the colloidal solution obtained on a TEM copper grid with holey carbon (Quantifoil). The micrographs were recorded with a JEOL 2100 operated at $200 \mathrm{keV}$. At least $200 \mathrm{NPs}$ imaged from at least three randomly selected areas of the grids were analyzed with the ImageJ software to establish the average diameter and deviation $(\sigma)$ of the NP size distribution.

\subsection{Colloidal Stability}

The relative colloidal stability was assessed by taking pictures of the solution at least every day for two weeks and assessing the presence of sedimented material at the bottom of the container.

\subsection{Headspace Gas Chromatography-Mass Spectroscopy (GC-MS)}

For headspace GC-MS, a headspace sampler (Agilent G1888 Network Headspace Sampler) connected to a gas chromatograph (Agilent 6890N Network GC System) with a mass spectrometer (Agilent 5973 inert Mass Selective Detector) was used. An Agilent 19091S-433 non-polar column was used (HP-5 ms (5\%-phenyl) methyl poly siloxane, $30.0 \mathrm{~m}$, $250 \mu \mathrm{m}, 0.25 \mu \mathrm{m})$. Chromatographs were recorded using a temperature ramp from 30 to $140{ }^{\circ} \mathrm{C}$ at $20^{\circ} \mathrm{C} \mathrm{min}^{-1}$.

\subsection{Fourier-Transform Infrared (FTIR) Spectroscopy}

For FTIR measurements, the as-prepared colloidal dispersions were dropped onto a ZnSe attenuated total reflection (ATR) crystal. An alkaline solution with the same solvent was used as background. The IR spectra were recorded in attenuated total reflectance 
mode on a Thermo-Nicolet Avatar 370 FT-IR spectrometer. All spectra were recorded with a resolution of $4 \mathrm{~cm}^{-1}$ and taking 50 scans.

\subsection{Electrochemical Characterization}

The electrocatalytic properties of the NPs were assessed by depositing $30 \mu \mathrm{L}$ of the asprepared NPs ( $0.5 \mathrm{mM}$ Pt solutions) directly onto a 5-mm-diameter glassy carbon electrode polished to mirror finish with 1.0- and 0.3- $\mu \mathrm{m}$ alumina oxide paste (AP-D suspension, Struer) [24]. The electrocatalytic activity was assessed at room temperature by cycling the as-prepared working electrode so obtained in a three-electrode configuration using a carbon rod as counter electrode and a saturated calomel electrode (SCE) as reference electrode. Fifty scans between -0.80 and $0.20 \mathrm{~V}_{\mathrm{SCE}}$ (converted to $\mathrm{V}$ vs. the reversible hydrogen electrode, $\mathrm{V}_{\mathrm{RHE}}$, using the relationship: $\mathrm{V}_{\mathrm{RHE}}=\mathrm{V}_{\mathrm{SCE}}+1.07 \mathrm{~V}$ ) were performed in $1 \mathrm{M}$ methanol with $1 \mathrm{M} \mathrm{KOH}$ aqueous solution.

\section{Results and Discussion}

\subsection{Colloidal Synthesis and Stabililty}

Our previous studies showed that a high water content leads to larger NPs and less controlled results $[17,20]$. The three spirits were chosen due to their relatively high ethanol content: $37.5 \%$ in volume. In a first set of experiments, the properties of Pt NPs obtained using $0.5 \mathrm{mM} \mathrm{H}_{2} \mathrm{PtCl}_{6}$ in $10 \mathrm{mM} \mathrm{NaOH}$ solution in Gin, Vodka, and Rum were compared (see Materials and Methods). The reaction mixtures, initially pale yellow, turned dark brown in all cases, indicative of the formation of Pt NPs (see Figure 1). The same occurred for a control experiment with $37.5 \mathrm{v} . \%$ ethanol in water.

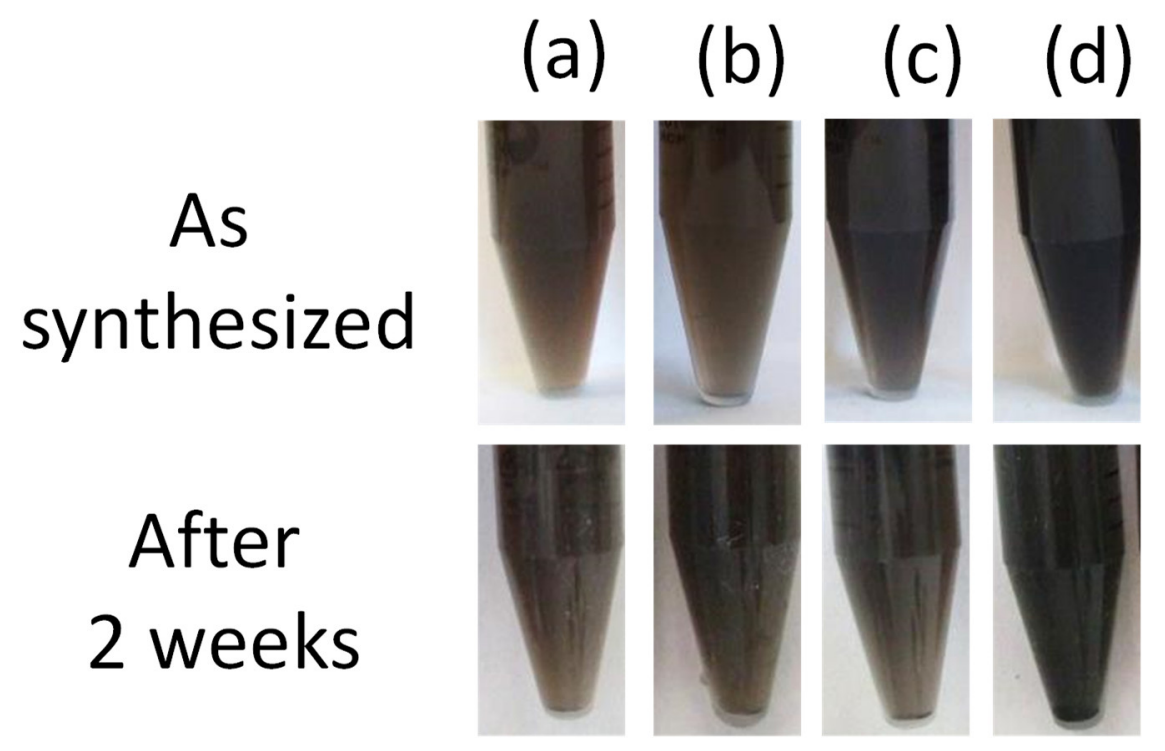

Figure 1. Pictures of the colloidal dispersions as synthesized and after two weeks for Pt nanoparticles obtained with $0.5 \mathrm{mM} \mathrm{H}_{2} \mathrm{PtCl}_{6}$ by microwave synthesis for alkaline solvents: (a) Control (37.5 v.\% ethanol in water), (b) Gin, (c) Vodka, and (d) Rum.

The sample obtained with alkaline Rum led to large NPs with an individual size around $5 \mathrm{~nm}(4.7 \pm 1.3 \mathrm{~nm})$ (see Table 1 and Figure 2). These NPs tended to agglomerate to form larger nanostructures. In the other three solvents, the NPs obtained were in the size range $2-3 \mathrm{~nm}: 2.8 \pm 1.0,2.2 \pm 0.7$, and $1.8 \pm 0.6 \mathrm{~nm}$ for, respectively, Control, Gin, and Vodka. All size distribution showed a tail toward larger size (Figure S1 in Supplementary Material), indicative of a growth mechanism by agglomeration and/or coalescence [17]. 
Table 1. Size and relative colloidal stability of the Pt NPs obtained in different solvents.

\begin{tabular}{ccccc}
\hline Solvent & Control & Gin & Vodka & Rum \\
\hline Particle size/nm & $2.8 \pm 1.0$ & $2.2 \pm 0.7$ & $1.8 \pm 0.6$ & $4.7 \pm 1.3$ \\
Relative deviation/\% & 35 & 32 & 35 & 27 \\
Relative colloidal stability & + & + & $+/-$ & - \\
\hline
\end{tabular}
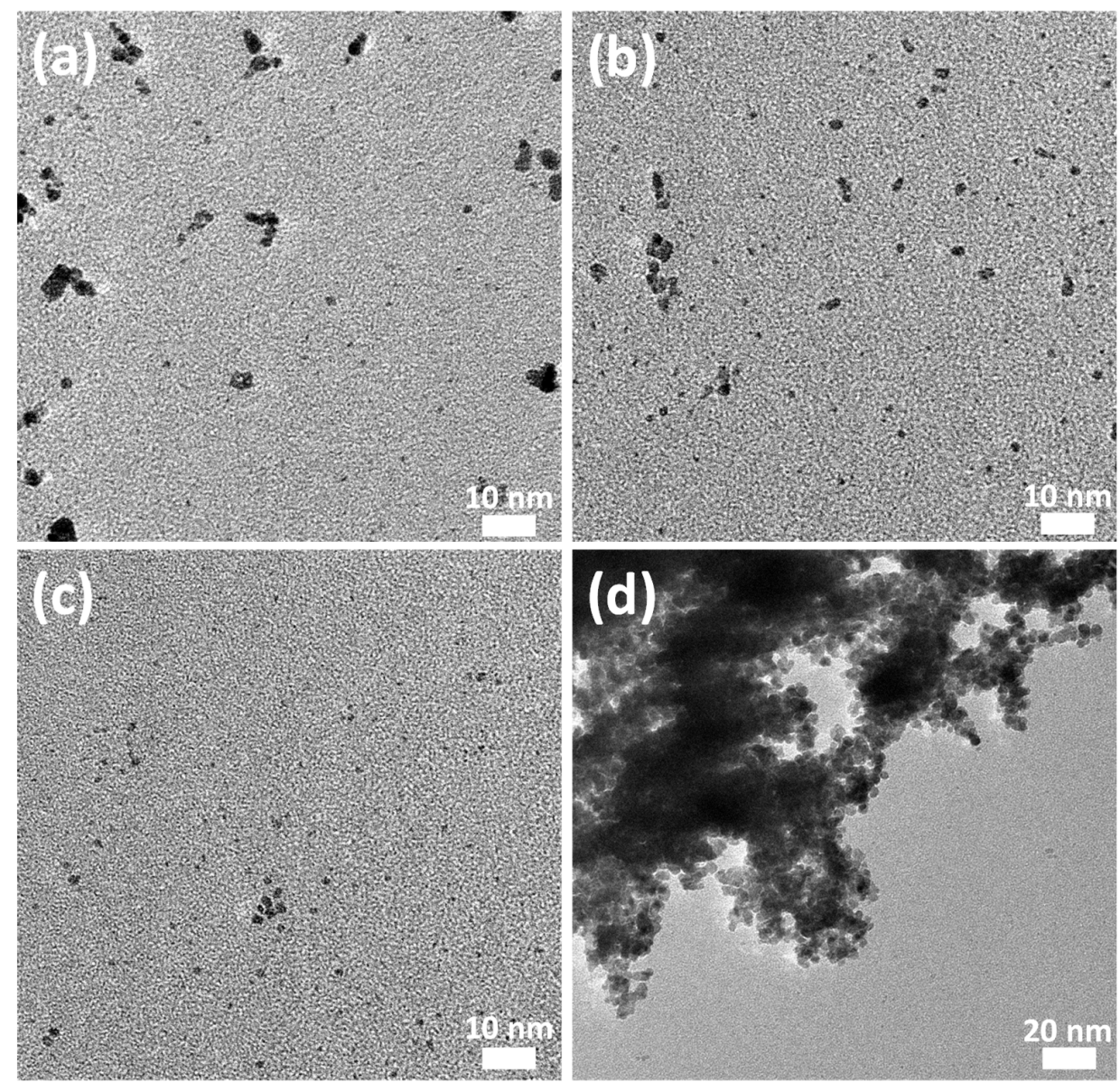

Figure 2. TEM micrographs of Pt NPs obtained as described in the text using alkaline (a) Control (37.5 v.\% ethanol in water), (b) Gin, (c) Vodka, and (d) Rum. See Figure S1 for size distribution.

Another important aspect is the stability of the colloids. For the Vodka- and Rumbased syntheses, NPs started to sediment after two weeks. In the case of the Rum-based synthesis, this was attributed to the larger size of the NPs and their tendency to agglomerate, confirmed by TEM. A better colloidal stability was achieved for the Control and the Ginbased solutions.

Commercial-grade spirits were complexed mixtures of water and ethanol with other chemicals $[25,26]$. Different sizes and colloidal stabilities achieved in different spirits were probably the result of different chemical compositions that influence the growth mechanisms and kinetics as well as the NP stability. A full analysis of the chemical compositions would be an extensive work and was not the focus of this report. To clarify the possible effect of possible additives on the NPs, we performed Fourier-transform infrared (FTIR) characterization. We could not assign specific bands to other compounds than ethanol or water (see Figure S2). We also could not observe the CO bands typically accounting for the functionalization of unprotected NPs $[17,27,28]$. This could have been due to the relatively low concentration of Pt NPs expected (less than $1 \mathrm{mg} \mathrm{mL}^{-1}$ ), but is also in agreement with previous work on Pt NPs prepared in alkaline ethanol [17,19]. We also 
attempted to perform headspace gas chromatography-mass spectroscopy characterization, but not obvious extra compounds, other than ethanol or water, could be identified (see Figures S3 and S4). By comparison of the chromatogram of the pure solvents, an indication of $\mathrm{CO}_{2}$ formation was suggested and signals related to the formation of acetaldehyde were observed (see Table S1). These products are consistent with the oxidation of ethanol, while $\mathrm{H}_{2} \mathrm{PtCl}_{6}$ was reduced during the NP synthesis [17].

To upscale the synthesis, we performed a same set of experiments, using $2.5 \mathrm{mM}$ of precursor, $50 \mathrm{mM}$ of $\mathrm{NaOH}$, and $1 \mathrm{~h}$ synthesis. For these conditions, no stable colloidal dispersions were obtained, large agglomerates were formed, and the material was not characterized further (see Figure S5). This observation is consistent with the fact that using alkaline ethanol leads to less stable colloidal dispersions, especially at higher platinum salt concentration and for longer synthesis time [17]. Interestingly, the solution turned color over time, indicating that further reaction happened after the NP synthesis (see Figure S5). This can be attributed to the reaction of alkaline ethanol to lead to products such as acetaldehyde and possibly further polymerization products $[17,29]$. These results stress the importance of a careful selection of the solvent to produce the NPs. This also shines light on the importance of processing quickly the NPs to avoid further side reactions of the solvent.

\subsection{Electrocatalytic Activity}

One of the benefits of a surfactant-free synthesis is to avoid any surfactant-removal steps, and the NPs obtained were readily suitable for electrocatalysis. Pt NPs are electrocatalysts for methanol oxidation, an energy-relevant reaction to develop fossil fuel-free societies [30]. Focus was given here to NPs obtained using alkaline Vodka as solvent since it led to the smallest NPs and, so, the NPs potentially offer a better use of the Pt resources for catalysis. Cyclic voltammograms in $1 \mathrm{M}$ methanol and $1 \mathrm{M} \mathrm{KOH}$ aqueous solutions showed two characteristic oxidation peaks at ca. 0.86 and $0.73 \mathrm{~V}_{\mathrm{RHE}}$ (see Figure 3). The peak of maximum current density corresponded to the oxidation of methanol and was obtained in the forward anodic scans, whereas the second peak of smaller current density was obtained on the backward cathodic scan. This second peak related to the removal of carbonaceous species on the Pt surface, formed during the forward anodic scan [31]. With an increasing number of cycles, the maximum recorded current density increased over time, indicating a possible cleaning and activation of the NPs (see Figure S6).

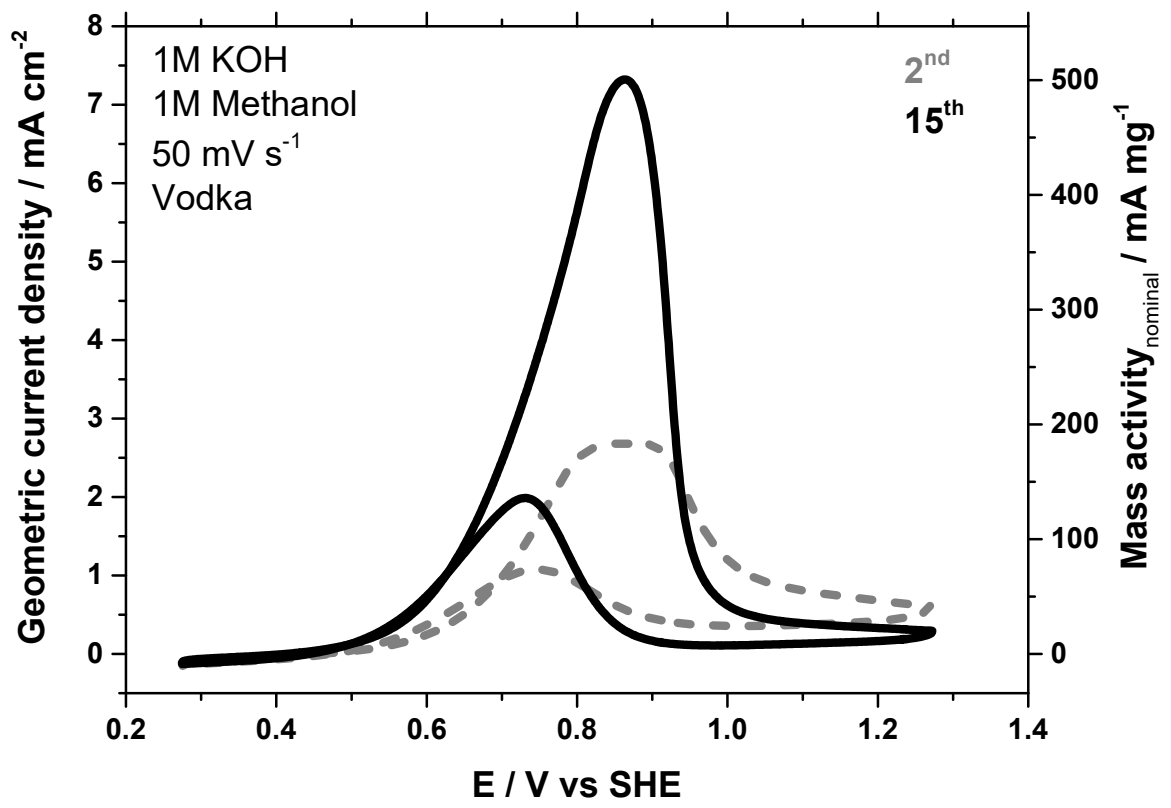

Figure 3. Cyclic voltammograms of Pt NPs prepared using vodka as solvent in $1 \mathrm{M} \mathrm{KOH}$ and $1 \mathrm{M}$ methanol aqueous solutions recorded at a scan rate of $50 \mathrm{mV} \mathrm{s}^{-1}$. The second (gray) and 15th (dark) scans are reported. 
The electrocatalysts obtained using Vodka were relatively stable, even though further cycling leads to a decrease of the current density, as expected for Pt nanocatalysts for methanol oxidation [32]. After ca. 15 cycles between 0.27 and $1.27 \mathrm{~V}_{\mathrm{RHE}}$, the oxidation reached a maximum current density of ca. $7.3 \mathrm{~mA} \mathrm{~cm}^{-2}$, which corresponded to ca. $500 \mathrm{~mA} \mathrm{mg}^{-1}$, based on the nominal loading. This value was reasonably high compared to the literature [32,33], considering that the NPs were obtained with a commercial spirit that is not a R\&D-grade solvent.

\section{Conclusions}

In conclusion, commercially available water-ethanol mixtures, like high-ethanol-content Gin, Vodka, or Rum, can be used to obtain Pt NPs by the alkaline Co4Cat ${ }^{\mathrm{TM}}$ process that was here shown to be robust regarding the nature and grade of solvent used. A full characterization of the solvents was not performed since this analytical task can be complex, but it was shown that commercial spirits like Gin and Vodka are suitable to produce stable colloidal dispersions of $\mathrm{Pt}$ NPs with a size around $2 \mathrm{~nm}$. This is a size range ideal for a range of applications. In particular, the NPs obtained using Vodka had the smallest size observed in this study, around $1.8 \mathrm{~nm}$, and show promising electrochemical activity.

This finding is directly relevant for further upscaling of the colloidal synthesis and the technical relevance of the synthesis for a wide range of study due to its robustness regarding different experiment conditions, like solvent grade.

\section{Patents}

The authors declare that the general synthesis Co4Cat ${ }^{\mathrm{TM}}$ method presented is subject to a patenting process (EP 3 329,990 A1, WO 2018/099,958 A1, US 16/464,773).

Supplementary Materials: The following are available online at https:/ / www.mdpi.com/2673-407 9/2/1/1/s1. Figure S1: Size distribution obtained from TEM micrographs analysis. Figure S2: FTIR spectra. Figure S3: Headspace GC-MS chromatograms before NP synthesis. Figure S4: Headspace GC-MS chromatograms after NP synthesis. Table S1: Summary of the peak observed by headspace GC-MS and possible attribution. Figure S5: Time evolution of Pt NP colloidal dispersions. Figure S6: Electrochemical characterization.

Author Contributions: Conceptualization, J.Q.; methodology, J.Q.; validation, J.Q.; formal analysis, J.Q.; investigation, J.Q.; resources, J.Q. and M.A.; writing—original draft preparation, J.Q.; writingreview and editing, J.Q., M.A., L.T.K. and S.B.S.; visualization, J.Q.; supervision, M.A. All authors have read and agreed to the published version of the manuscript.

Funding: M.A. acknowledges the support from the Villum Foundation in form of a block stipend. J.Q. acknowledges the European Union's Horizon 2020 research and innovation program under the Marie Skłodowska-Curie grant agreement No. 840523 (CoSolCat).

Data Availability Statement: The data presented in this study are available on request from the corresponding author.

Conflicts of Interest: The authors declare no conflict of interest. The funders had no role in the design of the study; in the collection, analyses, or interpretation of data; in the writing of the manuscript; or in the decision to publish the results".

\section{References}

1. Antolini, E. Structural parameters of supported fuel cell catalysts: The effect of particle size, inter-particle distance and metal loading on catalytic activity and fuel cell performance. Appl. Catal. B 2016, 181, 298-313. [CrossRef]

2. Chen, C.W.; Tano, D.; Akashi, M. Colloidal platinum nanoparticles stabilized by vinyl polymers with amide side chains: Dispersion stability and catalytic activity in aqueous electrolyte solutions. J. Colloid Interface Sci. 2000, 225, 349-358. [CrossRef] [PubMed]

3. Pradeep, T.; Anshup. Noble metal nanoparticles for water purification: A critical review. Thin Solid Films 2009, 517, 6441-6478. [CrossRef]

4. Rai, M.; Ingle, A.P.; Birla, S.; Yadav, A.; Dos Santos, C.A. Strategic role of selected noble metal nanoparticles in medicine. Crit. Rev. Microbiol. 2016, 42, 696-719. [CrossRef] [PubMed]

5. Duan, H.H.; Wang, D.S.; Li, Y.D. Green chemistry for nanoparticle synthesis. Chem. Soc. Rev. 2015, 44, 5778-5792. [CrossRef]

6. Charitidis, C.A.; Georgiou, P.; Koklioti, M.A.; Trompeta, A.-F.; Markakis, V. Manufacturing nanomaterials: From research to industry. Manuf. Rev. 2014, 1, 11. [CrossRef] 
7. Tsuzuki, T. Commercial scale production of inorganic nanoparticles. Int. J. Nanotechnol. 2009, 6, 567-578. [CrossRef]

8. Quinson, J.; Jensen, K.M.Ø. From platinum atoms in molecules to colloidal nanoparticles: A review on reduction, nucleation and growth mechanisms. Adv. Colloid Interface Sci. 2020, 286, 102300. [CrossRef]

9. Fievet, F.; Ammar-Merah, S.; Brayner, R.; Chau, F.; Giraud, M.; Mammeri, F.; Peron, J.; Piquemal, J.-Y.; Sicarda, L.; Viaub, G. The polyol process: A unique method for easy access to metal nanoparticles with tailored sizes, shapes and compositions. Chem. Soc. Rev. 2018, 47, 5187-5233. [CrossRef]

10. Cookson, J. The Preparation of Palladium Nanoparticles. Platin. Met. Rev. 2012, 56, 83-98. [CrossRef]

11. Niu, Z.Q.; Li, Y.D. Removal and Utilization of Capping Agents in Nanocatalysis. Chem. Mater. 2014, 26, 72-83. [CrossRef]

12. Huang, W.X.; Hua, Q.; Cao, T. Influence and Removal of Capping Ligands on Catalytic Colloidal Nanoparticles. Catal. Lett. 2014, 144, 1355-1369. [CrossRef]

13. Cargnello, M.; Chen, C.; Diroll, B.T.; Doan-Nguyen, V.V.T.; Gorte, R.J.; Murray, C.B. Efficient Removal of Organic Ligands from Supported Nanocrystals by Fast Thermal Annealing Enables Catalytic Studies on Well-Defined Active Phases. J. Am. Chem. Soc. 2015, 137, 6906-6911. [CrossRef] [PubMed]

14. Li, D.G.; Wang, C.; Tripkovic, D.; Sun, S.H.; Markovic, N.M.; Stamenkovic, V.R. Surfactant Removal for Colloidal Nanoparticles from Solution Synthesis: The Effect on Catalytic Performance. ACS Catal. 2012, 2, 1358-1362. [CrossRef]

15. Quinson, J.; Neumann, S.; Wannmacher, T.; Kacenauskaite, L.; Inaba, M.; Bucher, J.; Bizzotto, F.; Simonsen, S.B.; Kuhn, L.T.; Bujak, D.; et al. Colloids for Catalysts: A Concept for the Preparation of Superior Catalysts of Industrial Relevance. Ang. Chem. Int. Ed. 2018, 57, 12338-12341. [CrossRef]

16. Bizzotto, F.; Quinson, J.; Zana, A.; Kirkensaard, J.J.K.; Dworzak, A.; Oezaslan, M.; Arenz, M. Ir nanoparticles with ultrahigh dispersion as oxygen evolution reaction (OER) catalysts: Synthesis and activity benchmarking. Catal. Sci. Technol. 2019, 9, 6345-6356. [CrossRef]

17. Quinson, J.; Neumann, S.; Kacenauskaite, L.; Bucher, J.; Kirkensgaard, J.J.K.; Simonsen, S.B.; Theil Kuhn, L.; Zana, A.; Vosch, T.; Oezaslan, M.; et al. Solvent-dependent growth and stabilization mechanisms of surfactant-free colloidal Pt nanoparticles. Chem. Eur. J. 2020, 26, 9012-9023. [CrossRef]

18. Quinson, J.; Mathiesen, J.K.; Schroder, J.; Dworzak, A.; Bizzotto, F.; Zana, A.; Simonsen, S.B.; Theil Kuhn, L.; Oezaslan, M.; Jensen, K.M.Ø.; et al. Teaching old precursors new tricks: Fast room temperature synthesis of surfactant-free colloidal platinum nanoparticles. J. Colloid Interface Sci. 2020, 577, 319-328. [CrossRef]

19. Quinson, J.; Kacenauskaite, L.; Schroder, J.; Simonsen, S.B.; Kuhn, L.T.; Vosch, T.; Arenz, M. UV-induced syntheses of surfactantfree precious metal nanoparticles in alkaline methanol and ethanol. Nanoscale Adv. 2020, 2, 2288-2292. [CrossRef]

20. Quinson, J.; Kacenauskaite, L.; Bucher, J.; Simonsen, S.B.; Kuhn, L.T.; Oezaslan, M.; Kunz, S.; Arenz, M. Controlled Synthesis of Surfactant-Free Water-Dispersible Colloidal Platinum Nanoparticles by the Co4Cat Process. ChemSusChem 2019, 12, 1229-1239. [CrossRef]

21. Quinson, J.; Bucher, J.; Simonsen, S.B.; Theil Kuhn, u.; Kunz, S.; Arenz, M. Monovalent alkali cations: Simple and eco-friendly stabilizers for surfactant-free precious metal nanoparticle colloids. ACS Sustain. Chem. Eng. 2019, 7, 13680-13686. [CrossRef]

22. Lettenmeier, P.; Majchel, J.; Wang, L.; Saveleva, V.A.; Zafeiratos, S.; Savinova, E.R.; Gallet, J.J.; Bournel, F.; Gago, A.S.; Friedrich, K.A. Highly active nano-sized iridium catalysts: Synthesis and operando spectroscopy in a proton exchange membrane electrolyzer. Chem. Sci. 2018, 9, 3570-3579. [CrossRef] [PubMed]

23. Liz-Marzan, L.M.; Kagan, C.R.; Millstone, J.E. Reproducibility in Nanocrystal Synthesis? Watch Out for Impurities! ACS Nano 2020, 14, 6359-6361. [CrossRef] [PubMed]

24. Inaba, M.; Quinson, J.; Bucher, J.R.; Arenz, M. On the Preparation and Testing of Fuel Cell Catalysts Using the Thin Film Rotating Disk Electrode Method. J. Vis. Exp. 2018. [CrossRef]

25. Wisniewska, P.; Sliwinska, M.; Dymerski, T.; Wardencki, W.; Namiesnik, J. The analysis of raw spirits-A review of methodology. J. Inst. Brew. 2016, 122, 5-10. [CrossRef]

26. Zhao, Y.P.; Zheng, X.P.; Song, P.; Sun, Z.L.; Tian, T.T. Characterization of Volatiles in the Six Most Well-Known Distilled Spirits. J. Am. Soc. Brew. Chem. 2013, 71, 161-169. [CrossRef]

27. Schrader, I.; Warneke, J.; Neumann, S.; Grotheer, S.; Swane, A.A.; Kirkensgaard, J.J.K.; Arenz, M.; Kunz, S. Surface Chemistry of "Unprotected" Nanoparticles: A Spectroscopic Investigation on Colloidal Particles. J. Phys. Chem. C 2015, 119, 17655-17661. [CrossRef]

28. Baranova, E.A.; Bock, C.; Ilin, D.; Wang, D.; MacDougall, B. Infrared spectroscopy on size-controlled synthesized Pt-based nano-catalysts. Sur. Sci. 2006, 600, 3502-3511. [CrossRef]

29. Sauer, M.L.; Ollis, D.F. Photocatalyzed oxidation of ethanol and acetaldehyde in humidified air. J. Catal. 1996, 158, 570-582. [CrossRef]

30. Antolini, E.; Gonzalez, E.R. Alkaline direct alcohol fuel cells. J. Power Sources 2010, 195, 3431-3450. [CrossRef]

31. Zhang, L.J.; Xia, D.G. Electrocatalytic activity of ordered intermetallic PtSb for methanol electro-oxidation. Appl. Surf. Sci. 2006, 252, 2191-2195. [CrossRef]

32. Huang, W.; Wang, H.; Zhou, J.; Wang, J.; Duchesne, P.N.; Muir, D.; Zhang, P.; Han, N.; Zhao, F.; Zeng, M.; et al. Highly active and durable methanol oxidation electrocatalyst based on the synergy of platinum-nickel hydroxide-graphene. Nat. Commun. 2015, 6, 10035. [CrossRef] [PubMed]

33. Lu, S.; Li, H.; Sun, J.; Zhuang, Z. Promoting the methanol oxidation catalytic activity by introducing surface nickel on platinum nanoparticles. Nano Res. 2018, 11, 2058-2068. [CrossRef] 